\title{
Growth parameters of Holstein-Friesland heifers reared on complete diets containing different roughages
}

\author{
C. J. C. Muller* and J. A. Botha \\ Department of Agriculture, Western Cape, Private Bag X1, Elsenburg 7607, South Africa
}

\begin{abstract}
At two months of age, 48 Holstein-Friesland heifers were randomly allocated to four treatments comprising untreated wheat straw (WS), oven-ammoniated wheat straw (AWS), lucerne hay (LH) or oat hay (OH). Least cost nutrient balanced complete diets were formulated for heifers of different age groups, i.e. 2-6, 6-10, 10-13, 13-18 months and 18 months to first calving. Dry matter (DM) intakes of individual heifers were determined twice weekly. Animals were weighed once weekly, and girth circumference and wither height were measured monthly. From 13 months of age, heifers were observed daily for oestrus and inseminated provided that a minimum live weight of $290 \mathrm{~kg}$ had been attained. At two months of age, heifers weighed (mean \pm s.e.) $69 \pm 1.1 \mathrm{~kg}$ and wither height and girth circumference measured $84.6 \pm 0.4$ and $94.1 \pm 0.6 \mathrm{~cm}$ respectively. The average daily gain of heifers receiving diets containing LH was higher $(\mathrm{P}<0.001)$ from two months of age to calving than that of heifers receiving diets containing WS, AWS or OH (0.76vs. 0.68, 0.64 and $0.68 \mathrm{~kg} /$ day respectively). Heifers receiving $\mathrm{LH}$ diets were heavier $(\mathrm{P}<0.001)$ at first calving than heifers fed diets containing other roughages. Wither height at 22 months of age did not differ $(\mathrm{P}>0.05)$ between treatments, the overall mean being $129.3 \pm 0.5 \mathrm{~cm}$. Girth circumference of heifers fed diets containing WS, AWS and OH was smaller $(\mathrm{P}<0.001)$ than that of heifers fed LH $(179.2,177.3$ and $176.7 \mathrm{~cm} v s .188 .3 \mathrm{~cm}$ respectively). Heifers fed diets containing LH also had higher $(\mathrm{P}<0.01)$ condition scores than heifers fed diets containing other roughages. The lower feeding cost of AWS diets in comparison to other diets should be utilized fully in the rearing of replacement heifers.
\end{abstract}

Keywords: Heifer, dairy, Holstein, Friesland, cow, milk, nutrition

*Author to whom correspondence should be addressed; E-mail: carelm@wcape.agric.za

\section{Introduction}

The annual replacement rate of cows in dairy herds varies between 25 and $40 \%$. Heifer rearing is thus an integral part of any dairy herd. Rearing of heifers represents about $20 \%$ of the total expenses associated with milk production (Heinrichs, 1993); the most effective way to reduce this expenditure is to shorten the rearing period. Heifers calving at 23 months of age produce more milk by 61 months of age than heifers calving at 26.5 months of age. Using profit functions, Gill \& Allaire (1976) indicated that the optimal age at first calving for Holstein heifers was 22.5-23.5 months, provided that the animals are of adequate size. The average age at first calving of Holstein-Friesland heifers in the Western Cape is 27 months (Anon, 1988/89), indicating that rearing practices are less than ideal. Heifers are generally well fed until about five to six months of age. After that age, heifers in the Western Cape region are usually kept in large groups on fields of wheat stubble and/or receive untreated or ammoniated wheat straw supplemented with limited amounts of concentrates. Other roughages that are available include oat hay and lucerne hay; however, these roughages are generally used for feeding dairy cows, and only limited amounts are fed to replacement heifers. There is little information on the growth rates of heifers reared on diets containing locally available roughages. Van Dyk \& Brand (1977) compared the growth rate of Friesland heifers fed lucerne silage plus a concentrate supplement to that of heifers fed an oat / lucerne hay mixture (50:50) plus a high-protein supplement. The average daily gain of heifers receiving the hay mixture was higher than that of heifers fed lucerne silage, i.e. $0.576 \mathrm{vs} .0 .481 \mathrm{~kg} /$ day. These weight gains are, however, much lower than current recommendations.

More accurate balancing of diets according to the protein and energy requirements of growing heifers will result in more efficient growth, younger ages at first calving and increased profits for the producer. This may be achieved by changing the diets according to the age of the animal (NRC, 1989).

Less than 5\% of dairy farmers in the Swartland area of the Western Cape weigh heifers regularly (Baard, 1989). Limited information is therefore available on the growth rate of heifers sired by South African bred Holstein-Friesland bulls. There is also no information available on the daily feed intake of heifers fed diets containing locally available roughage sources. This trial was conducted to determine the growth rate, girth circumference and wither height of South African bred Holstein-Friesland heifers reared on untreated and ammoniated wheat straw, oat hay and lucerne hay.

\section{Materials and methods}

Forty-eight heifers from the Elsenburg Holstein-Friesland herd weighing $55-78 \mathrm{~kg}$ at two months of age were used in this trial. Heifers were left with their dams for at least $24 \mathrm{~h}$ after birth to consume colostrum. After removal from their 
dams, calves were weighed and put in individual calf pens. They were fed whole milk twice daily ( 4 l/d) by bucket until five weeks of age. A calf starter meal containing $18 \% \mathrm{CP}$ and $11.09 \mathrm{MJ} \mathrm{ME} / \mathrm{kg}$ DM was offered ad libitum from 5 days of age. At two months of age, heifers were allocated to one of four treatments consisting of diets containing different roughage sources. They were untreated wheat straw (WS), oven-ammoniated wheat straw (AWS), lucerne hay (LH) and oat hay $(\mathrm{OH})$. The treatment for the first calf was chosen randomly, with subsequent calves being allocated alternately to the other treatments. It was sometimes necessary to reverse the allocating order to minimize the difference in mean initial body weight between treatment groups (Cruywagen et al., 1996). Least-cost complete diets were formulated according to NRC (1989) standards for heifers of different age groups (Table 1).

Table 1 Composition and nutrient content of complete diets containing different roughages fed to Holstein-Friesland heifers from two-months of age to first calving

Ingredients

\begin{tabular}{llllll}
$\mathrm{kg})$ & $2-6$ & $6-10$ & $10-13$ & $13-18$ & $18-\mathrm{calving}$ \\
\hline
\end{tabular}

AWS WS LH OH AWS WS LH OH AWS WS LH OH AWS WS LH OH AWS WS LH OH

\begin{tabular}{|c|c|c|c|c|c|c|c|c|c|c|c|c|c|c|c|c|c|c|c|c|}
\hline AWS & 400 & - & - & - & 455 & - & - & - & 495 & - & - & - & 605 & - & - & - & 700 & - & - & \\
\hline WS & - & 325 & - & - & - & 390 & 120 & - & - & 430 & 195 & - & - & 525 & 245 & 200 & - & 607 & 300 & 305 \\
\hline LH & - & - & 460 & - & - & - & 400 & - & - & - & 350 & - & - & - & 400 & - & - & - & 445 & \\
\hline $\mathrm{OH}$ & - & - & - & 480 & - & - & - & 652 & - & - & - & 700 & - & - & - & 522 & - & - & - & 500 \\
\hline Maize & 250 & 250 & 250 & 50 & 150 & 150 & 150 & 35 & 50 & 50 & 50 & - & 100 & 100 & 100 & - & 76 & 75 & 75 & \\
\hline Wheat & 135 & 115 & 100 & 100 & 165 & 165 & 167 & - & 255 & 255 & 245 & - & 155 & 155 & 140 & 40 & 100 & 100 & 85 & \\
\hline Wheat bran & 25 & 80 & 95 & 150 & 150 & 150 & 150 & 150 & 150 & 150 & 150 & 150 & 100 & 100 & 100 & 100 & 76 & 75 & 75 & \\
\hline CSOCM & 150 & 195 & 65 & 185 & 65 & 130 & 5 & 150 & 30 & 100 & - & 130 & 20 & 105 & - & 118 & 28 & 128 & - & 150 \\
\hline Fish-meal & 20 & 20 & 20 & 20 & - & - & - & - & - & - & - & - & - & - & - & - & - & - & - & \\
\hline Bone-meal & 10 & - & 5 & - & - & - & 3 & - & 5 & - & 5 & - & 10 & 5 & 10 & - & 14 & 5 & 10 & \\
\hline Feedlime & 5 & 10 & - & 10 & 10 & 10 & - & 8 & 10 & 10 & - & 15 & 5 & 5 & - & 5 & 6 & 5 & 10 & \\
\hline Salt & 5 & 5 & 5 & 5 & 5 & 5 & 5 & 5 & 5 & 5 & 5 & 5 & 5 & 5 & 5 & 15 & - & 5 & - & \\
\hline
\end{tabular}

Estimated chemical composition of experimental diets within age group $(\mathrm{g} / \mathrm{kg})$

\begin{tabular}{|c|c|c|c|c|c|}
\hline $\mathrm{CP}$ & 150 & 120 & 111 & 101 & 101 \\
\hline $\mathrm{ME}(\mathrm{MJ} / \mathrm{kg})$ & 10.0 & 9.23 & 8.84 & 8.34 & 7.80 \\
\hline $\mathrm{CF}$ & 156 & 180 & 192 & 221 & 249 \\
\hline $\mathrm{ADF}$ & 216 & 244 & 260 & 296 & 333 \\
\hline $\mathrm{NDF}$ & 374 & 438 & 467 & 506 & 552 \\
\hline $\mathrm{Ca}$ & 5.8 & 4.9 & 4.9 & 4.3 & 4.5 \\
\hline $\mathrm{P}$ & 4.4 & 3.9 & 3.8 & 3.7 & 3.5 \\
\hline
\end{tabular}

CSOCM, Cotton seed oil cake meal; AWS, Ammoniated wheat straw; WS, Untreated wheat straw; LH, Lucerne hay; OH, Oat hay; ME: Metabolizable energy; CP, Crude protein; Ca, Calcium; P, Phosphorus; CF, Crude Fibre; ADF, Acid detergent fibre; NDF, Neutral detergent fibre

Heifers were housed in individual stalls. They were left in a dry lot from 10:30-14:00 for exercise and group interaction. Fresh feed was provided daily at 08:00 after removal of refusals from the previous day. Dry matter (DM) intakes were determined twice weekly. Animals were weighed once weekly at 08:00, before feeding. The daily feed allowance was adjusted weekly according to body weight using NRC (1989) standards. The amount of feed DM provided was $2.75,2.35,2.25,2.20$ and $2.35 \%$ of body weight for the age groups $2-6,6-10,10-13,13-18$ months and 18 months until first calving respectively. Girth circumference and wither height were measured monthly. From 13 months of age, heifers were put in a dry lot after the afternoon feeding (from 16:00 onwards) and observed during early evening for signs of estrus. Heifers were inseminated when a minimum live weight of $290 \mathrm{~kg}$ was attained. The animals were fed a complete diet ad libitum after first calving. The diet contained 15\% CP and 10.2 MJ ME/kg DM. Milk production parameters of cows were calculated for partial (105 days) and completed (300 days) lactations. Breeding values of heifers that have 
completed a standard 300-day lactation period were obtained from the National Dairy Cattle Performance Testing Scheme, and were used as a co-variant to correct milk production parameters between treatments.

Variables collected at different ages (i.e. live weight and DM intake) were analyzed by one-way analysis of variance (Little and Hills, 1972). Significance was declared at $\mathrm{P}<0.05$.

\section{Results and discussion}

The effect of roughage source on DM intake is presented in Table 2. Heifers receiving LH diets had higher $(\mathrm{P}<0.01)$ intakes at all ages than heifers receiving diets containing other roughage sources. The higher intakes of LH diets are probably related to the lower NDF contents relative to the other diets (Table 1). According to Sharma et al. (1982), a higher NDF content usually reduces intake. Poore et al. (1989) found that neither milk yield, nor milk components were affected by roughage source when diets were formulated to contain similar levels of NDF.

Table 2 Mean dry matter (DM) intake of Holstein-Friesian heifers fed complete diets containing different roughages from 2 to 22 months of age

\begin{tabular}{|c|c|c|c|c|c|c|}
\hline \multirow{2}{*}{$\begin{array}{c}\text { Age } \\
\text { (months) }\end{array}$} & \multicolumn{4}{|c|}{ DM-intake (kg DM/day) } & \multirow{2}{*}{ SEM } & \multirow{2}{*}{$\mathrm{P}$} \\
\hline & WS & AWS & LH & $\mathrm{OH}$ & & \\
\hline 2 & 1.30 & $0.92^{\mathrm{ab}}$ & $1.62^{\mathrm{a}}$ & $1.42^{\mathrm{b}}$ & 0.08 & 0.025 \\
\hline 4 & 2.78 & $2.38^{\mathrm{a}}$ & $3.04^{\mathrm{a}}$ & 2.70 & 0.08 & 0.043 \\
\hline 6 & $3.50^{\mathrm{a}}$ & $3.17^{\mathrm{b}}$ & $3.97^{\mathrm{abc}}$ & $3.35^{\mathrm{c}}$ & 0.07 & 0.003 \\
\hline 8 & $3.96^{\mathrm{a}}$ & $3.59^{\mathrm{b}}$ & $4.64^{\mathrm{abc}}$ & $3.99^{c}$ & 0.07 & 0.0001 \\
\hline 10 & $4.70^{\mathrm{a}}$ & $4.32^{\mathrm{b}}$ & $5.64^{\mathrm{abc}}$ & $4.63^{c}$ & 0.10 & 0.0001 \\
\hline 12 & $5.74^{\mathrm{a}}$ & $5.23^{\mathrm{b}}$ & $6.57^{\mathrm{abc}}$ & $5.79^{c}$ & 0.11 & 0.0007 \\
\hline 14 & $6.29^{\mathrm{a}}$ & $5.56^{\mathrm{b}}$ & $7.07^{\mathrm{abc}}$ & $6.13^{\mathrm{c}}$ & 0.14 & 0.003 \\
\hline 16 & $6.79^{\mathrm{a}}$ & $6.36^{\mathrm{b}}$ & $8.08^{\mathrm{abc}}$ & $7.18^{\mathrm{c}}$ & 0.15 & 0.002 \\
\hline 18 & $7.80^{\mathrm{a}}$ & $7.05^{\mathrm{bc}}$ & $9.00^{\mathrm{abd}}$ & $8.05^{\mathrm{cd}}$ & 0.13 & 0.0001 \\
\hline 20 & $8.85^{\mathrm{a}}$ & $7.60^{\mathrm{ab}}$ & $9.82^{\mathrm{bc}}$ & $7.95^{\mathrm{c}}$ & 0.18 & 0.0004 \\
\hline 22 & 9.34 & $8.70^{\mathrm{a}}$ & $9.96^{\mathrm{a}}$ & 8.99 & 0.19 & 0.12 \\
\hline
\end{tabular}

WS: Untreated wheat straw; AWS: Oven ammoniated wheat straw; LH: Lucerne hay; OH: Oat hay; SEM: Standard error of the mean; P: Significance level; abc: Means within rows with similar superscripts differ significantly $(\mathrm{P}<0.05)$

Live weight of heifers at two months of age was $69 \pm 7.5 \mathrm{~kg}$ (Table 3 ) and did not differ $(\mathrm{P}>0.05)$ between treatments. According to Holtz et al. (1992), Holstein heifers in 13 selected Wisconsin dairy herds weighed $78 \mathrm{~kg}$ at two months of age while recommendations for heifers in the USA are that they should be $84 \mathrm{~kg}$ at this age. From 4 months of age onwards, heifers receiving $\mathrm{LH}$ diets were heavier $(\mathrm{P}<0.01)$ than heifers fed diets containing other roughages. Average daily gain $(\mathrm{ADG})$ of heifers from two months of age to first calving differed $(\mathrm{P}<0.01)$ between roughage treatments. Age at first calving (24.3 \pm 0.3 months) did not differ $(\mathrm{P}>0.05)$ between treatments. Gardner et al. (1977) showed that earlier calving (19.7 vs. 26.9 months) had no negative effect on milk production over three lactations. The ADG of heifers receiving WS, AWS, LH and OH diets was $0.68,0.64,0.76$ and $0.68 \mathrm{~kg} /$ day respectively. According to Holtz et al. (1992), Holstein heifers should weigh at least $600 \mathrm{~kg}$ at 24 months. This is equivalent to a liveweight gain of more than $0.75 \mathrm{~kg} / \mathrm{day}$. Similarly, the NRC (1989) recommends that dairy heifers should weigh 550-600 kg at calving at 24 months of age. Bortone et al. (1994) recommends that Holstein heifers should grow at $0.70 \mathrm{~kg} /$ day from 3-24 months of age, calve down at 24 months of age at a live weight of at least $550 \mathrm{~kg}$. According to Daccaret et al. (1993) heifers weighing $155 \mathrm{~kg}$ at 6 months of age in their experiment were under weight. In the present trial heifers weighed between 128 and $157 \mathrm{~kg}$ at the same age, indicating that they are also under weight in terms of American growth standards. Israeli heifers (Peri et al., 1993) weighed 244, 275 and $304 \mathrm{~kg}$ at approximately 10 months of age after receiving diets described as restricted (85\% of NRC, 1989 recommendations), control and ad libitum intakes. Live weights of these heifers were similar to those obtained at 12 months in the present study, probably indicating that South African bred Holsteins are smaller than Israeli Holsteins. The lower live weight and ADG to first calving are probably related to a smaller body size, as heifer calves in this herd weigh approximately $35 \mathrm{~kg}$ at birth while Holstein heifers in the USA weighed $43 \mathrm{~kg}$ at birth (Holtz et al., 1992). Kertz et al. (1997) reported a mean birth weight of $40 \mathrm{~kg}$ for female calves for all parities in a US Holstein herd. 
Table 3 Mean live weight of Holstein-Friesland heifers fed complete diets with different roughage sources from two months of age until first calving

\begin{tabular}{|c|c|c|c|c|c|c|}
\hline \multirow{2}{*}{ Age (months) } & \multicolumn{4}{|c|}{ Live weight (kg) } & \multirow{2}{*}{ SEM } & \multirow{2}{*}{$\mathrm{P}$} \\
\hline & WS & AWS & LH & $\mathrm{OH}$ & & \\
\hline 2 & 70 & 66 & 70 & 69 & 1.1 & 0.55 \\
\hline 4 & $105^{\mathrm{a}}$ & $92^{\mathrm{ab}}$ & $108^{\mathrm{b}}$ & 102 & 1.8 & 0.08 \\
\hline 6 & $143^{\mathrm{a}}$ & $128^{\mathrm{abc}}$ & $157^{\text {bd }}$ & $142^{\text {cd }}$ & 2.5 & 0.002 \\
\hline 8 & $180^{\mathrm{a}}$ & $164^{\mathrm{b}}$ & $203^{a b c}$ & $181^{\mathrm{c}}$ & 3.2 & 0.001 \\
\hline 10 & $223^{a}$ & $208^{\mathrm{b}}$ & $256^{\mathrm{abc}}$ & $228^{\mathrm{c}}$ & 3.8 & 0.001 \\
\hline 12 & $270^{\mathrm{a}}$ & $257^{\mathrm{b}}$ & $303^{\mathrm{abc}}$ & $274^{\mathrm{c}}$ & 4.7 & 0.009 \\
\hline 14 & $310^{\mathrm{a}}$ & $291^{\mathrm{b}}$ & $346^{\mathrm{abc}}$ & $314^{\mathrm{c}}$ & 4.9 & 0.003 \\
\hline 16 & $350^{\mathrm{a}}$ & $325^{\mathrm{b}}$ & $389^{\mathrm{abc}}$ & $352^{c}$ & 4.9 & 0.001 \\
\hline 18 & $394^{\mathrm{a}}$ & $367^{\mathrm{b}}$ & $437^{\mathrm{abc}}$ & $392^{\mathrm{c}}$ & 5.5 & 0.001 \\
\hline 20 & $440^{\mathrm{ab}}$ & $403^{\mathrm{ac}}$ & $485^{\text {bcd }}$ & $434^{\mathrm{d}}$ & 5.9 & 0.0002 \\
\hline 22 & $484^{\mathrm{a}}$ & $450^{\mathrm{b}}$ & $532^{\mathrm{abc}}$ & $475^{\mathrm{c}}$ & 6.5 & 0.0006 \\
\hline Pre-calving live weight & $515^{\mathrm{a}}$ & $509^{b}$ & $580^{\mathrm{abc}}$ & $529^{c}$ & 7.5 & 0.007 \\
\hline
\end{tabular}

WS: Untreated wheat straw; AWS: Oven ammoniated wheat straw; LH: Lucerne hay; OH: Oat hay; SEM: Standard error of

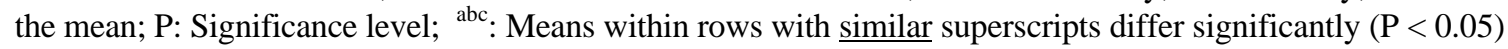

Differences in live weight at calving and ADG in this experiment are probably related to DM intake, which differed $(\mathrm{P}<0.01)$ between roughage sources, specifically between LH and the other roughage sources. Total feed consumed from two months of age until first calving was 4334, 4214,5033 and $4144 \mathrm{~kg}(\mathrm{P}<0.01)$ for heifers receiving complete diets with WS, AWS, $\mathrm{LH}$ and $\mathrm{OH}$ as roughage respectively.

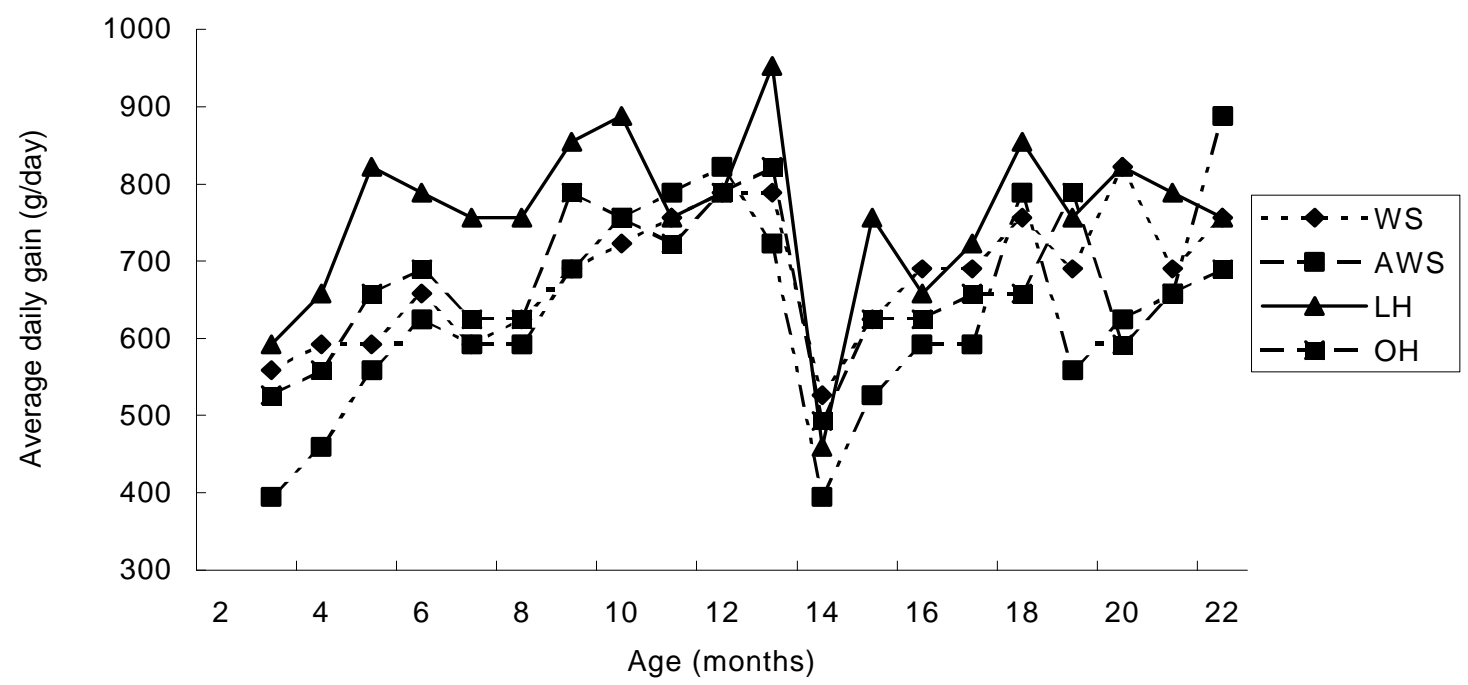

Figure 1 Average daily gain (g/day) of Holstein-Friesian heifers fed complete diets with different roughage sources from two to 22 months of age

The ADG of heifers from two to 22 months of age is presented in Figure 1. With the exception of heifers receiving LH diets, heifers only reached the minimum ADG of $0.65 \mathrm{~kg}$ /day during month 9. This may have been due to the protein quality of the diets, as only $2 \%$ of the total diet consisted of fish-meal, while cotton seed oilcake meal provided the bulk of the protein for heifers from two to six months of age. The use of fish-meal and soy-bean meal as protein sources resulted in higher $(\mathrm{P}<0.05)$ weight gains for Holstein bull calves from 9 to 21 weeks of age in comparison to corn gluten meal and 
cotton seed meal (Zerbini \& Polan, 1985). The lower ADG during month 14 in comparison with month 13 (0.468 vs. 0.822 $\mathrm{kg} /$ day), resulted from the change in management necessary for oestrus detection; time away from feed resulted in a lower ADG during months 14 and 15 for heifers in all treatments.

Girth circumference at two months of age did not differ $(\mathrm{P}>0.05)$ between treatments (Figure 2).

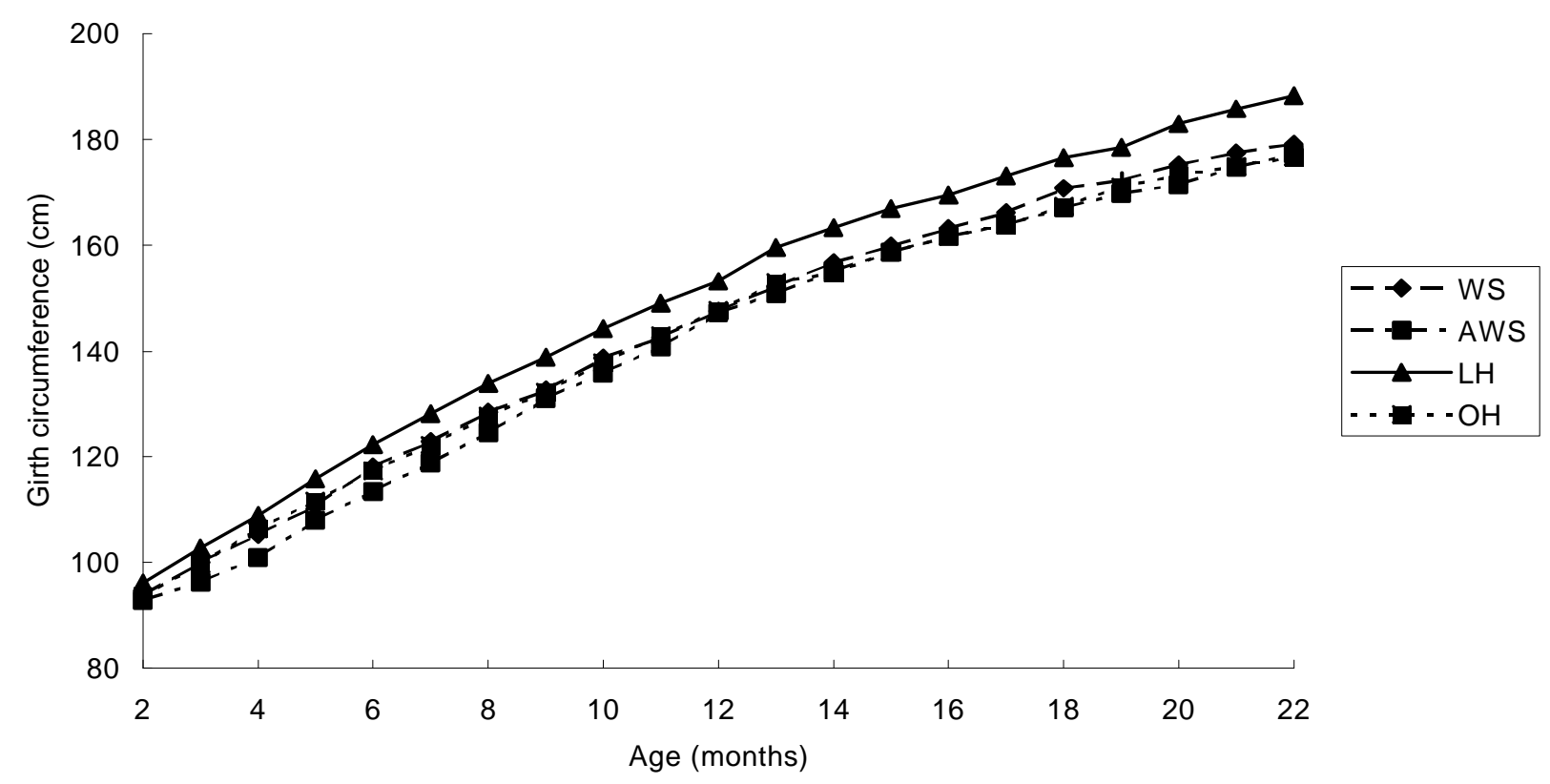

Figure 2 Girth circumference of Holstein-Friesian heifers fed complete diets containing different roughage sources from two to 22 months of age

From three months of age girth circumference for the LH diet was larger than that for the WS, AWS and OH diets. This is probably related to body condition score, as heifers offered the LH diet had higher condition scores that those fed the other diets. Using the Mulvaney (1977) condition scoring technique, the condition score of heifers fed the LH diet increased from 2.5 at 12 months of age to 3.4 at 24 months of age. At 12 months of age, the condition score of heifers fed the WS, AWS and $\mathrm{OH}$ diets was 2.0, and increased to 2.6, 2.4 and 2.6 respectively. Heifers receiving LH diets gained more than $0.75 \mathrm{~kg} / \mathrm{day}$. They clearly showed higher fat deposition as indicated by a higher body condition score and girth circumference. Heifers gaining $0.68 \mathrm{~kg} /$ day (WS and $\mathrm{OH}$ groups) showed no excessive fat accumulation, probably indicating that a higher growth rate would be excessive for animals of a similar type. It appears that the higher growth rate of LH-heifers in comparison to that of heifers fed other diets is probably related more to fat deposition than skeletal growth.

The effect of roughage source on wither height is presented in Figure 3. From seven to 14 months of age, heifers fed on LH diets had higher $(\mathrm{P}<0.05)$ wither heights than heifers fed on AWS diets. However, at 22 months of age differences in wither height between treatments were small $(2 \mathrm{~cm})$. These heifers were, however, smaller than recommended in the USA. According to Holtz et al. (1982) height of withers at 22 months should be $137 \mathrm{~cm}$, while heifers in this experiment only reached approximately $130 \mathrm{~cm}$. 


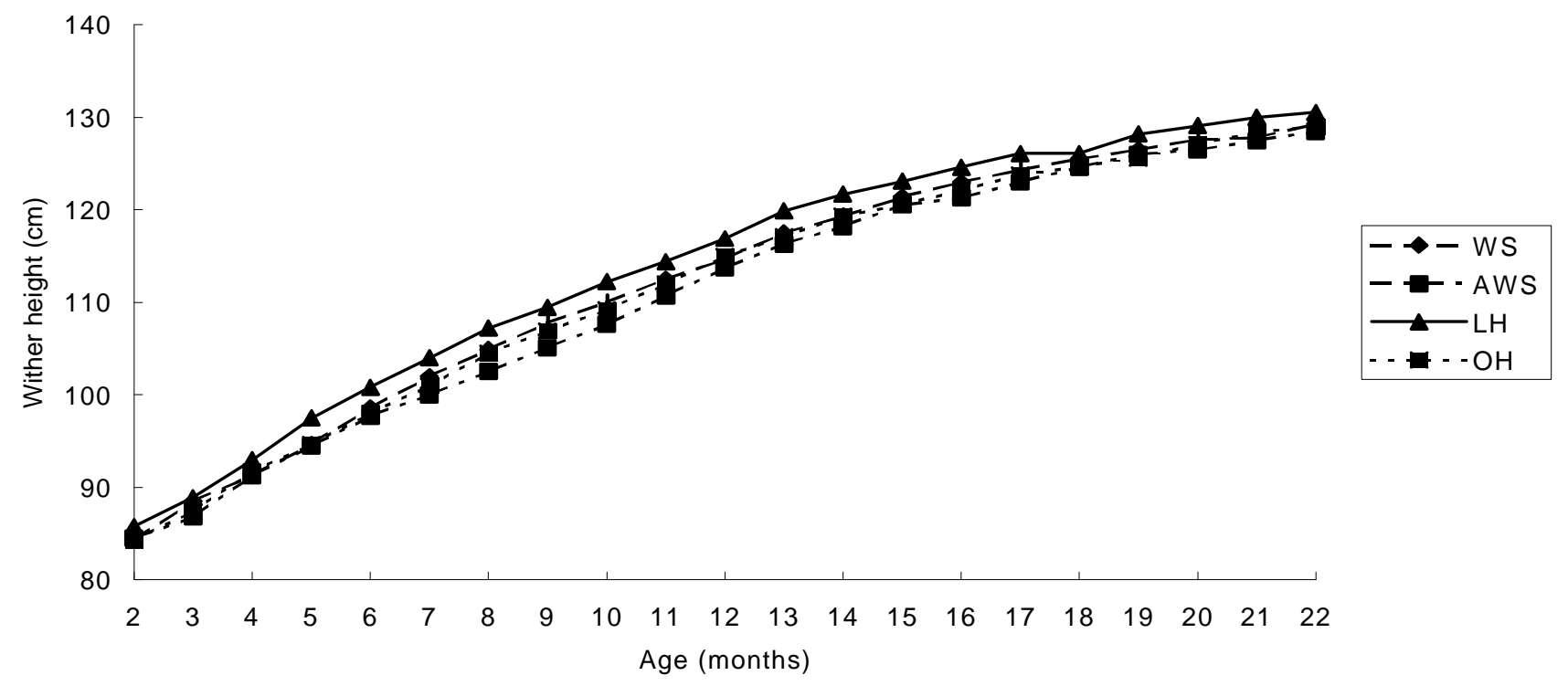

Figure 3 Wither height of Holstein-Friesian heifers fed diets with different roughage sources from two to 22 months of age

Simard \& Marchand (1995) showed positive correlations between live weight and first lactation yields of milk, milk fat and milk protein for Canadian Holsteins. Animals with a live weight of more than $650 \mathrm{~kg}$ produced more milk than animals with live weight of less than $450 \mathrm{~kg}$. Results of this study showed that South African bred Holstein-Friesland heifers could obtain a live weight of at least $510 \mathrm{~kg}$ at first calving at 24 months of age without being over-conditioned. Heifers weighing $580 \mathrm{~kg}$ at 24 months were probably over-conditioned (average condition score $=3.4$ ). Rapid growth rates are desirable to produce heifers with adequate body weight and size at first calving. Excessive body weight gain during the prepubertal period may, however, be counterproductive. Gardner et al. (1977) showed that high levels of dietary energy before puberty are detrimental to future milk production. Fattening of heifers during this period may decrease the future milk-producing ability of heifers because the milk secretory tissue of fatty mammary glands is reduced.

Milk production during first lactation of heifers reared on diets containing different roughages was not affected (P $>0.05$ ) by roughage type. Holstein-Friesland heifers reared on WS, AWS, LH and OH diets produced 2 427, 2355,2545 and $2240 \mathrm{~kg}$ milk respectively during the first 105 days of the lactation. Not all cows completed their first lactation because of various reasons, namely death, poor reproduction and standard culling procedures. Milk production over the standard lactation tended $(\mathrm{P}=0.10)$ to differ between rearing treatments, with cows reared on $\mathrm{LH}$ and $\mathrm{OH}$ diets producing the most milk (7 126 and $6909 \mathrm{~kg}$ ). In comparison, cows reared on the WS and AWS diets produced 6425 and $6435 \mathrm{~kg}$ milk. However, milk production did not differ $(\mathrm{P}>0.05)$ between treatments when corrected for breeding values, and was 6 684, 6 591, 6820 and $6682 \mathrm{~kg}$ milk for the WS, AWS, LH and OH diets respectively. It could be argued that heifers that were reared on LH did not perform according to expectations as they had a higher body condition score. Heifers receiving $\mathrm{LH}$ weighed $71 \mathrm{~kg}$ more than the AWS group but only produced $229 \mathrm{~kg}$ more milk, equivalent to only $3.2 \mathrm{~kg}$ milk per kg extra bodyweight at calving. The response should have been in excess of $6 \mathrm{~kg}$ milk per additional $\mathrm{kg}$ bodyweight. Over-conditioned heifers at calving are not desired because such animals have poor appetites, show greater body weight losses during the lactation and also produce less milk during the lactation. They may also experience dystocia and metabolic disorders, such as fat cow syndrome. The balancing of rations for growing ruminants requires special attention. Requirements of the growing animal are constantly changing, and growth rate should be monitored regularly (Van Amburgh et al., 1992). Heinrichs (1993) suggested that feed intake and growth of individual heifers must be monitored on farms at regular intervals to reduce costs and to avoid impairing lifetime performance.

In this trial, diet cost (R/ton) decreased with age, owing to a decrease in nutritional requirements with age, but total feed cost increased because of higher feed intakes. Total feed cost from two months of age to first calving varied $(\mathrm{P}<0.01)$ between R1 715 (AWS diets) to R2 473 (LH diets). Mouritz et al. (1997) found that cumulative feed cost was reduced by about $15 \%$ by reducing the rearing period from 26 to 22 months. In the present trial total feed cost increased by R2.22, R1.06, R6.67 and R5.06/day with increasing age at first calving from 22 to 28 months of age for diets containing WS, AWS, $\mathrm{LH}$ and $\mathrm{OH}$ as roughages. 


\section{Conclusions}

Heifers reared on diets containing LH as roughage had higher growth rates than heifers reared on WS, AWS and OH diets, resulting in heifers being heavier and larger in terms of girth circumference at first calving. The growth rate of heifers receiving AWS did not differ $(\mathrm{P}>0.05)$ from that of heifers fed WS and $\mathrm{OH}$. Growth rates on the latter three diets were sufficient to attain the minimum growth parameters for live weight, size and condition required to ensure highly productive animals during first lactation. The lower feeding cost of AWS diets in comparison to other roughage diets should be utilized in the rearing of replacement heifers.

\section{References}

Anonymous, 1988/89. Breed, regional and herd averages of grade en registered Frieslands. Region 1. Vol. 9. 1 September 1988 to 31 August 1989. National Dairy Cattle Performance and Progeny Testing Scheme. Animal and Dairy Science Research Institute, Private Bag X2, Irene 1675.

Baard, J.A.J., 1989. Verslag oor melkbeesboerderye in die Winterreënstreek. 2. Swartlandsubstreek. Dept. Landbou: Wes-Kaap, Privaatsak X1, Elsenburg.

Bortone, E.J., Morrill, J.L., Stevenson, J.S. and Feyerherm, A.M., 1994. Growth of heifers fed 100 or $115 \%$ of National Research Council requirements to 1 year of age and then changed to another treatment. J. Dairy Sci. 77, 270-277.

Cruywagen, C.W., Jordaan, I. and Venter, L., 1996. Effect of Lactobacillus acidophilus supplementation of milk replacer on preweaning performance of calves. J. Dairy Sci. 79, 483-486.

Daccarett, M.G., Bortone, E.J., Isbell, D.E., Morrill, J.L. and Feyerherm, A.M., 1993. Performance of Holstein heifers fed $100 \%$ or more of National Research Council requirements. J. Dairy Sci. 76, 606-614.

Gardner, R.W., Schuh, J.D. and Vargus, L.G., 1977. Accelerated growth and early breeding of Holstein heifers. J. Dairy Sci. 60, 1941-1948.

Gill, G.S. and Allaire, F.R., 1976. Relationship of age at first calving, days open, days dry and herd life to a profit function for dairy cattle. J. Dairy Sci. 59, 1131-1134.

Heinrichs, A.J., 1993. Raising dairy replacements to meet the needs of the 21st century. J. Dairy Sci. 76, 3179-3187.

Holtz, C.R., Van Amburgh, M. and Galton, D.M., 1992. Dairy replacements - third class citizens on many dairy farms. Should an increased management priority be given to them? North East Winter Dairy Management Schools. Dept. of Anim. Sci. Cornell Univ. pp. 41-66.

Kertz, A.F., Reutzel, L.F., Barton, B.A. and Ely, R.L., 1997. Body weight, body condition score, and wither height of prepartum Holstein cows and birth weight and sex of calves by parity: A database and summary. J. Dairy Sci. 80, $525-529$.

Little, T.M. and Hills, F.J., 1972. Statistical methods in agricultural research. Univ. California. Davis. California.

Mouritz, M.C.M., Dijkhuizen, A.A., Huirne, R.B.M. and Galligan, D.T., 1997. Technical and economic models to support heifer management decisions: Basic concepts. J. Dairy Sci. 80, 1406-1415.

NRC, 1989. Nutrient requirements of dairy cattle. National Research Council, 6th rev. ed. Natl. Acad. Sci. Washington DC.

Mulvaney, P., 1977. Dairy cow condition scoring. NIRD Paper no 4468. National Institute for Research in Dairying, Shinfield, Reading, UK.

Peri, I., Gertler, A., Bruckental, I. and Barash, H., 1993. The effect of manipultion in energy allowance during the rearing period of heifers on hormone concentrations and milk production in first lactation cows. J. Dairy Sci. 76, 742-751.

Poore, M.H., Moore, J.A., Swingle, R.S., Eck, T.P., Brown, W.H. and Whiting, F.M., 1989. Influence of alfalfa hay or wheat straw fibre in 30\% NDF diets on milk production and rate of passage in Holstein cows. J. Anim. Sci. (Suppl. 1), 491. (Abstr.)

Sharma, H.R. Ingalis, J.R. and Guenter, W., 1982. Evaluation of steam-treated wheat straw as a roughage source in dairy cow rations. Can. J. Anim. Sci. 62, 181-190.

Simard, J. and Marchand, D., 1995. Raising heifers: What a challenge! Dairy Sci. Abstr. 57, 840. (Abstr.)

Tamminga, S., 1979. Protein degradation in the forestomachs of ruminants. J. Anim. Sci. 49, 1615-1620.

Van Amburgh, M., Galton, D., Fox, D. and Bauman, D., 1992. Opportunities exist to optimize dairy heifers growth. Feedstuffs 64(14), 12-13, 17.

Van Dyk, J. de K. and Brand, C.J.J., 1977. Hooi as enigste ruvoer vir die grootmaak van verse vir kuddeverplasing. Els. J. 1(6), 1-2.

Zerbini, E. and Polan, C.E., 1985. Protein sources evaluated for ruminating Holstein calves. J. Dairy Sci. 68, 1416-1424. 